\title{
Research in Library and Information Science in South Africa: an analysis of journal research output from I993-2006
}

\author{
Dennis N. Ocholla ' and Lyudmilla Ocholla ${ }^{2}$ \\ Department of Library and Information Science, \\ University of Zululand Library, University of Zululand, South Africa \\ docholla@pan.uzulu.ac.za, locholla@pan.uzulu.ac.za
}

Received : $25^{\text {th }}$ May 2007

Accepted: $28^{\text {th }}$ June 2007

\begin{abstract}
This paper intends to promote an awareness of the overall research output in library and information science in South Africa, and is based on a publication count and analysis of peer refereed articles indexed in the LISA and Thompson Scientific (formely ISI) Web of Science databases (SCI,SSCI,A\&HCI) between 1993 and 2006, using journal, subject and author indicators for the analysis. The recommendations are in favour of expanding the publication threshold by diversifying the output such that it includes currently marginalised domains.
\end{abstract}

Key Words: Research; Library and Information Science; South Africa

\section{Introduction}

Whereas there is no consensus on the best way to measure research output in a given discipline, most members of the scientific community, particularly those in favour of quantitative measures of research (see ISSI conferences), concur that peer refereed journals offer a verifiable platform/source of measuring the research productivity of scholars. Even in this area, there is a strongly held view that the journal impact factor [of peer refereed journals] (e.g. determining the degree of cited-ness of articles in a journal) should be used to determine the most important and influential research journals and research papers/articles in a discipline. The Citation Impact Factor (CIF), proposed by Eugene Garfield in 1969 (Garfield, $1994: 4 \mathrm{II}$ ), is defined as the average number of citations in a given year of articles published in a journal in the preceding two years. Normally, citations received in one year are divided by papers published in the two previous years in order to obtain the ratio. The approach used to determine the quality of research has therefore not been uniform. Evidently, there are those who are in favour of qualitative measures of research (e.g. Gorman 2000, Calvert and Gorman 2002) and also strong proponents of peer review as a measure of research quality (e.g. Harnad 1995 ${ }^{3}$ ). Similarly, there are those who are in favour of citation analysis and the journal impact factor as a quantitative measure of research output (e.g. Garfield I97I, 1972,1994, 1998). For example, when defending qualitative measures of journal quality as opposed to quantitative measures based on citedness or the impact factor, Calvert and Gorman argue that "The fact that paper $\mathrm{x}$ is cited $\mathrm{y}$ times is not an indicator of quality, but rather that it is cited -it is available, it is in the journal held by many libraries, the author (or publisher or editor) is particularly good at self-promotion" (Calvert and Gorman 2002:I). Harnad has always provided peer review with overwhelming support and defence. In one of his seminal articles on peer review he (Harnad 1998: paragraph one) argues that journals should not be free from the "process of peer review, whose 'invisible hand' is what maintains its quality". Although other forms of research output, such as books, conference proceedings, reviews, theses and dissertations, patents, and other research reports of limited circulation are used to measure research output, journal articles are still the most dominant, favoured and easily verifiable for quality control in scientific research. Each country, and in some cases institution, determines its research quality in different ways. For example, a quality research output in South Africa will appear in a prescribed list of 255 South African Journals ${ }^{4}$, Thompson Scientific (ISI) databases ${ }^{5}$ and IBSS databases ${ }^{6}$, and will not include correspondence with the editors, abstracts or extended abstracts, obituaries, book reviews, news articles and advertorials. For each article published in such a journal, a substantial government research subsidy - which in itself is regularly revised and increased - is paid to the author's affiliate institution, which then decides on how to share the subsidy with the authors/contributor.

The first part of this analysis was based on the output of graduate (masters and doctoral) dissertations and theses from 1993 to 2000 , as reported at the $66^{\text {th }}$ IFLA conference held in Jerusalem (Ocholla, 2000). The variables included gender,

I. Dennis Ocholla (PhD) is Professor and Head of the Department of Library and Information Science, University of Zululand as well as Editor-in-Chief, South African Journal of Libraries and Information Science, South Africa.

2. Lyudmilla Ocholla is Information Librarian, University of Zululand Library, South Africa.

3. http://www. princeton.edu/ harnad

4. http://www.education.gov.za

5. http://www.isinet.com/isi/journals/index.html

6. http://www.Ise/ac/uk/collections/IBSS/access/Default.htm 
language, population group, institutional affiliation, subject, and the quantity and output of both masters and doctoral theses over that period. It was observed that the preponderance of theses was produced at masters level in the English language by women, and that the universities of Natal [now KwaZulu-Natal] - Pietermaritzburg campus, Pretoria, and the Rand Afrikaans University (now the University of Johannesburg) lead in productivity. Additionally, the multidisciplinary nature of information science exhibited elements of boundary crossing, collaboration and borrowing from computer science, business management, geography, music and political science in graduate research output. Although this analysis has not been extended to 2006 due to the closure (in 200I) of the unit previously indexing research output at Potchestroom University (now part of the University of the North West), the productivity pattern reported by Ocholla (2000) has not changed much. However, there are marginal variations, for example other universities that did not feature well in that study (such as the University of Zululand) have made significant progress during the last six years, more publications are emerging from the formerly marginalised communities largely through co-publication with established researchers/postgraduate masters and doctoral research supervisors.

Bibliometric/Informetric studies are widely used to inform policies and decisions in political, economic, social and technological domains affecting information flow and the use pattern within, between and outside institutions and countries. Although Library and Information Science (LIS) studies of this nature solve problems related to collection development, information retrieval, systems design, user studies, management, and knowledge organisation, among others, in Africa bibliometric studies are limited. Those focusing on LIS are insignificant, with the exception of a few studies reported largely by West African scholars such as Aina (1998), Aina and Mabawonku (1997), Aina and Mooko (1999), Alemna and Badu (1994), Alemna (1996; 200I), Kadiri (200I), and Mabawonku (200I). There are a few noted studies in South Africa by Boon and Van Zyl (1990), Ocholla (2000: 200I) and Ngulube (2005a; 2005b). This study adds to the cited studies by providing, in general, an awareness of the overall research output from within the Library and Information Science discipline in South Africa based on a publication count of peer refereed articles appearing in national and international LIS journals, specifically those indexed in LISA and ISI databases. This is in order to determine whether diversification and output with regard to authors, journals and subject coverage and research collaboration has occurred over the period. The paper therefore attempts to address the following questions: In which journals do the LIS authors (SA) publish and why? What is the publication rate and trend overall, and particularly between 1993 and 2006? What are the overall publication counts by author and comparatively between LISA and ISI during the period? What is the authors' overall publication count, cites and ratio in ISI Web of Science, and what is the publication trend by leading authors during this period? In what subject domains are the articles published? What is the type and nature of research collaboration? What are the author's institutional affiliations? And what are the implications of the data to LIS research in South Africa?

\section{Methodology}

Publication count and analysis was used to determine the nature, type and range of research output in Library and Information Science in South Africa. The productivity of authors was analysed using the parameters outlined in the research questions in the preceding section. A master list of 218 LIS researchers (both potential/novice and established) was compiled from authors of masters and doctoral dissertations/theses appearing in the South African Bibliographic Network (SABINET) on-line from 1993-2000 largely used in part one of this study (see Ocholla 2000). The list has been supplemented by 220 names of authors appearing in the South African Journal of Library and Information Science between 1993 and 2006, Mouisaion from 2003-2006, South African Journal of Information Management from 2004 - 2006, and Innovation (unfortunately it is neither indexed as a peer refereed Journal by LISA nor indexed in Web of Science) in 2006 based on the dates when the journals were recognised and included in the list of research journals by the Department of Education of South Africa (i.e. for government research quality recognition and publication subsidy purposes). After filtering the list and discarding names of authors who have not published in peer refereed journals indexed in LISA and Thompson Scientific (ISI), 250 authors' names were selected and included in the master list for further searches. Both Library and Information Science Abstracts (LISA) and ISI Web of Science (includes the Science Citation Index Expanded File $[\mathrm{SCl}]$ and Social Sciences Citation Index File $[\mathrm{SSCl}]$ and Arts and Humanities Citation Index File (A\&HSI) databases were targeted in order to search for each author's journal publication record. Only articles in peer refereed journals appearing in LISA were selected from the database, while only journal articles were selected from ISI Web of Science. LISA is considered to be one (besides of course, Information Science Abstracts (ISA) and Library Information Science and Technology Abstracts - LISTA) of the largest LIS abstract databases, indexing, among others, well over 550 periodicals/ journals from over 60 countries in 20 different languages. Journals appearing in LISA are also categorised into peer refereed journals. Thompson Scientific Web of Science $(\mathrm{SCl}, \mathrm{SSCl} A \& \mathrm{HCl})$ indexes the most important, credible and

7. http://www.ifla.org//V/ifla66/papers/054-/27e.htm

SA Jnl Libs \& Info Sci 2007, 73(2) 
influential research publications, largely articles assumed to exhibit a significant impact factor on a given discipline. This includes over 8,830 titles from 230 disciplines consisting of 6,125 active journals and I 45 highly cited book series from $\mathrm{SCl}, 1800$ active journal titles and 30 highly cited book series in $\mathrm{SSCl}$ as well as I, I30 active journals and I5 highly cited book series in A\&HCl. Only authors producing one or more peer refereed articles in LISA were selected for the analysis. Of the 250 authors, only 67 were indexed in ISI Web of Science. Upon creating an author authority list, searches were done in the two databases by author name, which was much easier in ISI authors' finder because a search with author surname yields all the other initials or string name combinations for that author, and more complicated in LISA, where author name combinations are complicated. Data was captured and downloaded in Excel spreadsheets and organised by author name, frequency of publications, by database (ISI and LISA), source/format of publication (e.g. Journal), the subject domain developed from the subject descriptors, and nature of collaboration (developed from the author list and addresses only from ISI). An analysis was conducted with the help of descriptive and inferential statistics using Excel software programs. The Pivot Table in Excel made the analysis extremely flexible and relatively simple. The results are provided in the next section.

\section{Results and discussions}

The results are categorised by journal, author, subject, and collaboration output.

\subsection{Output in LISA and ISI journals}

A total of 157 journals (titles) generated 1216 articles produced by 250 authors (this includes authors appearing in both LISA and ISI), of which 67 were also based in ISI . Of the I 57 journals, $87(54.4 \%)$ and $70(44.6 \%)$ were indexed by LISA and ISI respectively. The journals appearing in both LISA and ISI were 12 (7.6\%). The leading three journals, namely South African Journal of Libraries and Information Science (a Library and Information Association of South Africa-LIASA journal), Mousaion (University of South Africa-UNISA based) and the South African Journal of Information Management (University of Johannesburg based), produced 563 (46.3\%) of the total number of articles indexed in LISA based journals. Unfortunately, none of the three journals is indexed by ISI. Among the journals, $305(25.1 \%)$ articles came from South African Journal of Libraries and Information Science, I 45 (II.9\%) came from Mousaion, and II 3 (9.3\%) articles originated from the South African Journal of Information Management. These three Journals are also listed among three other journals (Indilinga: African Journal of Indigenous Knowledge, Innovation and ESARBICA) in the list of 255 South African journals (from all disciplines) selected for the research recognition and subsidies mentioned earlier. The top three non-South African Journals were LIBRI (36 articles in LISA and 32 in ISI), the African Journal of Library and Archives and Information Science (32 articles in LISA), and the Electronic Library (28 LISA and I8 ISI). Other journals with significant scores were Education for Information (26 LISA and 5 ISI), Library Management (24 for LISA), International Information and Library Review (22 LISA and I 3 ISI) and the Journal of Information Processing and Management (20 for LISA and 20 for ISI). Notably, unlike LISA, journal indexing in $|S|$ is inconsistent, as some journals are withdrawn by ISI upon failing to comply with their rigid indexing criteria (Table I- ISI section shows the demise of several journals between 1993-2006). Newcomers in the ISI indexing list, such as the Journal of Information Ethics, had no articles by South Africa based authors as yet indexed by ISI - perhaps because of the indexing time lag, i.e. the period between the publication of a paper in the public domain and the date it is captured in abstracting and indexing journals (see Diodato 1994) - despite ISI provision of access to accepted papers/ articles awaiting publication. The publication pattern as indexed in LISA and ISI between 1993 and 2006 is reflected in Table I.

Table I Publication output and trend in LISA and Web of Science (ISI), Journal and author 1993-2006

\begin{tabular}{|c|c|c|c|c|c|c|c|c|c|c|c|c|c|c|c|}
\hline JOURNALS: LISA & 1993 & 1994 & 1995 & 1996 & 1997 & 1998 & 1999 & 2000 & 2001 & 2002 & 2003 & 2004 & 2005 & 2006 & Total \\
\hline $\begin{array}{l}\text { South African Journal of Libraries and } \\
\text { Information Science }\end{array}$ & 35 & 30 & 36 & 35 & 37 & 27 & & 7 & 8 & 19 & 13 & 18 & 23 & 17 & 305 \\
\hline Mousaion & 10 & 12 & 14 & 20 & 9 & 9 & 6 & 5 & 8 & 8 & 10 & 16 & 18 & & 145 \\
\hline $\begin{array}{l}\text { South African Journal of Information } \\
\text { Management }\end{array}$ & & & & & & & & & & & 23 & 65 & 25 & & 113 \\
\hline Libri & & & 1 & & 1 & 2 & 4 & 4 & 2 & I & 8 & 6 & 6 & I & 36 \\
\hline $\begin{array}{l}\text { African Journal of Library, Archives and } \\
\text { Information Science }\end{array}$ & 2 & 3 & 2 & 4 & 4 & 2 & 2 & 2 & I & 4 & I & 2 & 3 & & 32 \\
\hline Electronic Library & 3 & & 5 & & 4 & & 6 & 1 & & & 5 & 1 & & 4 & 28 \\
\hline Education for Information & & & 2 & 3 & 1 & 2 & 3 & 1 & 2 & & 7 & 3 & 2 & & 26 \\
\hline Library Management & & & 2 & 1 & 2 & & 9 & 4 & & I & I & 1 & 1 & 2 & 24 \\
\hline
\end{tabular}

SA Jnl Libs \& Info Sci 2007, 73(2) 


\begin{tabular}{|c|c|c|c|c|c|c|c|c|c|c|c|c|c|c|c|}
\hline $\begin{array}{l}\text { International Information and Library } \\
\text { Review }\end{array}$ & 1 & 2 & I & 3 & 1 & 1 & & & 3 & 2 & & & 6 & 2 & 22 \\
\hline $\begin{array}{l}\text { Information Processing \& } \\
\text { Management }\end{array}$ & 1 & & 2 & 2 & & & 1 & 1 & 2 & & 2 & 3 & & 6 & 20 \\
\hline Aslib Proceedings & 1 & & & & & 2 & & 2 & 3 & 1 & 4 & 4 & & 1 & 18 \\
\hline $\begin{array}{l}\text { International Journal of Information } \\
\text { Management }\end{array}$ & 0 & & & & & 1 & & & 1 & & 1 & 3 & 2 & 3 & 11 \\
\hline Alexandria & 1 & 1 & 1 & 1 & & 2 & 1 & & 1 & 1 & 1 & & & & 10 \\
\hline Journal of Documentation & & & & & & 2 & & 1 & 3 & $\mathrm{I}$ & & & 1 & 2 & 10 \\
\hline Library Review & 1 & & 1 & & 1 & & 2 & 3 & & 1 & 1 & & & & 10 \\
\hline Information Research & & & & & & & & & 1 & 5 & & I & 1 & 1 & 9 \\
\hline Journal of Information Science & & 5 & & & & 1 & & & & & & 3 & & & 9 \\
\hline $\begin{array}{l}\text { Journal of Librarianship and } \\
\text { Information Science }\end{array}$ & I & 2 & & & 2 & & 1 & & & & & & & 1 & 7 \\
\hline $\begin{array}{l}\text { Library and Information Science } \\
\text { Research }\end{array}$ & & 1 & & & & & & & & & 2 & 2 & 1 & & 6 \\
\hline Interlending and Document Supply & 1 & & & 1 & & & & 1 & & 2 & & & & & 5 \\
\hline JOURNALS : Web of Science & 1993 & 1994 & 1995 & 1996 & 1997 & 1998 & 1999 & 2000 & 2001 & 2002 & 2003 & 2004 & 2005 & 2006 & Total \\
\hline Libri & & & 1 & & & 2 & 3 & 3 & 2 & 1 & 8 & 5 & 6 & 1 & 32 \\
\hline $\begin{array}{l}\text { Information Processing \& } \\
\text { Management }\end{array}$ & 1 & & 2 & 2 & & & 1 & 1 & 2 & & 2 & 3 & 6 & & 20 \\
\hline Electronic Library & 2 & & 3 & & & & 3 & 1 & & 1 & 5 & 1 & & 2 & 18 \\
\hline ASLIB Proceedings & $\mathrm{I}$ & & & & & 1 & & 2 & 3 & 1 & 3 & 2 & & 1 & 14 \\
\hline $\begin{array}{l}\text { International Information \& Library } \\
\text { Review }\end{array}$ & 1 & 2 & 1 & 1 & & & 2 & & & 1 & & & 3 & 2 & 13 \\
\hline Journal of Documentation & & & & & & 2 & & 1 & 3 & 1 & 1 & & 1 & 3 & 11 \\
\hline Journal of Information Science & & 2 & & & 2 & 1 & & & & & & 3 & & 2 & 10 \\
\hline $\begin{array}{l}\text { International journal of Information } \\
\text { Management }\end{array}$ & 0 & & & & & 1 & & & 1 & & 1 & 2 & 1 & 3 & 9 \\
\hline Reference \& User Services Quarterly & & & & & & & & 2 & 2 & 1 & I & 3 & & & 9 \\
\hline$R Q$ & 2 & 3 & 2 & 1 & 1 & & & & & & & & & & 9 \\
\hline Information Retrieval & & & & & & & & & 3 & & & 2 & & 2 & 7 \\
\hline $\begin{array}{l}\text { Journal of the American Society for } \\
\text { Information Science and Technology }\end{array}$ & 1 & & & & & & & & 3 & 1 & 1 & & & 1 & 6 \\
\hline College \& Research Libraries & & 1 & & & & & 1 & 1 & & 1 & 1 & & & & 5 \\
\hline Education for Information & & & 2 & 3 & & & & & & & & & & & 5 \\
\hline Journal of Government Information & & 1 & $\mathrm{I}$ & & & 3 & & & & & & & & & 5 \\
\hline $\begin{array}{l}\text { Journal of Librarianship and } \\
\text { Information Science }\end{array}$ & 1 & 1 & & & 1 & & 1 & & & & & & & 1 & 5 \\
\hline $\begin{array}{l}\text { Library \& Information Science } \\
\text { Research }\end{array}$ & & & & & & & & & & & 2 & 2 & I & & 5 \\
\hline $\begin{array}{l}\text { Context: Nature, Impact, and Role, } \\
\text { Proceedings }\end{array}$ & 0 & & & & & & & & & & & & 4 & & 4 \\
\hline $\begin{array}{l}\text { Information Research-An } \\
\text { International Electronic Journal }\end{array}$ & 0 & & & & & & & & & & 1 & 1 & 1 & 1 & 4 \\
\hline Interlending \& Document Supply & 1 & & & 1 & & & & 1 & & 1 & & & & & 4 \\
\hline
\end{tabular}

\subsection{Author publication pattern}

The analysis includes non-South African residents who have either produced co-authored articles with South African residents, published in South African LIS journals, completed their masters or doctoral studies in South African academic institutions, or lived/resided in South Africa before but migrated to other countries, as captured for the master list. As presented in Table 2, 250 authors published 960 articles indexed in the LISA database, while 67 published 256 articles (26.2\%) indexed in ISI databases. The top 4 most productive authors, whose articles are indexed in ISI, do not reside in South Africa, while all top 10 authors indexed in LISA, except for one, reside in South Africa. Furthermore, of the top 20 authors indexed in LISA, 15 are indexed in ISI. A total of 542 cites from 256 articles (average 2.2 cites paper article) are noted, with both the largest number of articles (4I- Jarvelin K., 13 - Pirkola A. and I I- Andersen, J; Siddiqui, M.A.) and 
cites (259-Jarvelin and 55-Pirkola) originating from non-residents. South African residents' highest cites originate from Cosijn's co-authored paper (of 2) with Ingwersen (25 cites), in the Journal of Information Processing and Management in 2000, Dick's one paper of 4 (I5 cites) in Library Quarterly in 1995, Behren's one article of one ( 25 cites), and Du Toit's I 8 cites (from 9 articles). The highest citation ratios originate from Behrens (25.00), Cosijn (12.50), Jarvelin (6.32), Mountifield (6.00), Jacobs (5.50), Pirkola (4.23), Dick (3.75) and Botha (2.67). Citation counts were only based on ISI Web of Science indicators. Only authors of two or more papers in LISA are represented in Table 2, while all the authors in ISI are included in the table.

Table 2 Publication output by author in LISA and ISI Web of Science

\begin{tabular}{|c|c|c|c|c|c|c|c|c|c|c|c|c|c|}
\hline \multirow[b]{2}{*}{ No } & \multirow{2}{*}{ Rank } & \multicolumn{4}{|l|}{ LISA $(\mathbf{N}=250)$} & \multirow[b]{2}{*}{ Author } & \multirow[b]{2}{*}{ Articles } & \multirow[b]{2}{*}{ No } & \multirow{2}{*}{ Rank } & \multicolumn{4}{|l|}{ ISI $(\mathbf{N}=67)$} \\
\hline & & Author & Articles & No & Rank & & & & & Author & Articles & Cites & Ratio \\
\hline $\mathrm{I}$ & 1 & Brakel, PA v & 31 & 69 & 21 & Theron, J C & 4 & 1 & 1 & Jarvelin, K & 41 & 259 & 6.32 \\
\hline 2 & 2 & Ocholla, DN & 28 & 70 & 21 & Tobin, Peter KJ & 4 & 2 & 2 & Pirkola, A; & 13 & 55 & 4.23 \\
\hline 3 & 3 & Toit, A S D d & 27 & 71 & 21 & Walt, MS vd & 4 & 3 & 3 & Andersen, J; & 11 & 17 & 1.55 \\
\hline 4 & 4 & Jarvelin, K; & 26 & 72 & 21 & Walker, CM & 4 & 4 & 3 & Siddiqui, MA & 11 & 14 & 1.27 \\
\hline 5 & 5 & Britz, J] & 24 & 73 & 21 & Weideman, Melius & 4 & 5 & 4 & Britz, J] & 9 & 10 & 1.11 \\
\hline 6 & 6 & Fourie, I & 23 & 74 & 21 & Auret, $\mathrm{HE}$ & 4 & 6 & 4 & Du Toit, ASA & 9 & 18 & 2.00 \\
\hline 7 & 7 & Lor, P J; & 21 & 75 & 23 & Darch, C; & 3 & 7 & 4 & Lor, PJ & 9 & 7 & 0.78 \\
\hline 8 & 8 & Dick, A L & 18 & 76 & 23 & Plessis, M D; & 3 & 8 & 4 & Snyman, RMM & 9 & 1 & 1.11 \\
\hline 9 & 9 & Aina, L O & 16 & 77 & 23 & Edwards, HM & 3 & 9 & 4 & Van Brakel, P & 9 & 5 & 1.08 \\
\hline 10 & 10 & Snyman, R & 15 & 78 & 23 & Geustyn, M; & 3 & 10 & 5 & Aina, LO & 8 & 5 & 0.63 \\
\hline 11 & 11 & Siddiqui, M A & 14 & 79 & 23 & Kok, J A & 3 & 11 & 6 & Fourie, I & 7 & 10 & 1.43 \\
\hline 12 & 11 & Stilwell, C & 14 & 80 & 23 & Kruger, Cornelius J. & 3 & 12 & 6 & Ocholla, DN & 7 & II & 1.57 \\
\hline 13 & 11 & Beer, C S d & 14 & 81 & 23 & Lange, M d; & 3 & 13 & 7 & Nassimbeni, M & 5 & 2 & 0.40 \\
\hline 14 & 12 & Snyman, M & 13 & 82 & 22 & Marais, $\mathrm{H}$; & 3 & 14 & 7 & Ngulube, $P$ & 5 & 2 & 0.40 \\
\hline 14 & 12 & Machet, MP & 13 & 83 & 22 & Mitchell, C & 3 & 15 & 8 & Boon, JA & 4 & 4 & 1.00 \\
\hline 15 & 13 & Moahi, K H; & 12 & 84 & 22 & Mooko, N P; & 3 & 16 & 8 & Chisenga, J; & 4 & 4 & 1.00 \\
\hline 16 & 13 & Nassimbeni, M & 12 & 85 & 22 & Morgan, G C & 3 & 17 & 8 & Dick, AL & 4 & 15 & 3.75 \\
\hline 17 & 13 & Olen, SI & 12 & 86 & 22 & Morris, C; & 3 & 18 & 8 & Ikoja-Odongo, R; & 4 & 3 & 0.75 \\
\hline 19 & 13 & Behrens, S J & 12 & 87 & 22 & Myers, G & 3 & 19 & 8 & Myers, G; & 4 & 3 & 0.50 \\
\hline 20 & 14 & Boon, J A & 11 & 88 & 22 & Plessis, M D; & 3 & 20 & 8 & Stilwell, C & 4 & 2 & 0.50 \\
\hline 21 & 14 & Bothma, TJ D & 11 & 89 & 22 & Popoola, SO & 3 & 21 & 9 & Botha, RA; & 3 & 8 & 2.67 \\
\hline 22 & 14 & Chisenga, J & 11 & 90 & 22 & Raju, R & 3 & 22 & 9 & de Hamel, C & 33 & 0 & 0.00 \\
\hline 23 & 14 & Jager, KD & 11 & 91 & 22 & Raubenheimer, J & 3 & 23 & 9 & du Plessis, M & 3 & 4 & 1.33 \\
\hline 24 & 14 & Kruger, J A & 11 & 92 & 22 & Roux, $P J A$ & 3 & 24 & 9 & Mabawonku, IM & 3 & 4 & 1.33 \\
\hline 25 & 14 & Ngulube, $\mathrm{P}$ & 11 & 93 & 22 & Singh, Anesh Maniraj & 3 & 25 & 9 & Moahi, KH & 3 & 0 & 0.00 \\
\hline 26 & 14 & Gericke, E M & II & 94 & 22 & Vuren, A J V; & 3 & 26 & 9 & Penzhorn, C & 3 & 3 & 1.00 \\
\hline 27 & 15 & Mabawonku, I M & 10 & 95 & 22 & Vermeulen, WM & 3 & 27 & 9 & Petkov, D & 3 & 3 & 1.00 \\
\hline 28 & 15 & Andersen, J & 10 & 96 & 22 & Aswegen, E S v & 3 & 28 & 10 & Adigun, MO & 2 & 0 & 0.00 \\
\hline 29 & 16 & Berner, $\mathrm{S}$ & 9 & 97 & 23 & Averweg, Udo; & 2 & 29 & 10 & Bothma, $T$ & 2 & 0 & 0.00 \\
\hline 30 & 16 & Muller, Marie-Luce & 9 & 98 & 23 & Baard, V C; & 2 & 30 & 10 & Cosijn, E; & 2 & 25 & 12.50 \\
\hline 31 & 16 & Pirkola, A; & 9 & 99 & 23 & Bornman, M & 2 & 31 & 10 & De Jager, K; & 2 & 1 & 0.50 \\
\hline 32 & 16 & Underwood, P G & 9 & 100 & 23 & Cloete, Marian; & 2 & 32 & 10 & Dube, L & 2 & 0 & 0.00 \\
\hline 33 & 16 & Hart, G & 9 & 101 & 23 & de Kock, M G & 2 & 33 & 10 & Heyns, Danielle; & 2 & 0 & 0.00 \\
\hline 34 & 17 & Ikoja-Odongo, J R & 8 & 102 & 23 & Deventer, MJ v; & 2 & 34 & 10 & Jacobs, D; & 2 & 11 & 5.50 \\
\hline 35 & 17 & Pienaar, $\mathrm{H}$ & 8 & 103 & 23 & Doyle, D; & 2 & 35 & 10 & Lubbe, S & 2 & 2 & 1.00 \\
\hline 36 & 17 & Mostert, B J & 8 & 104 & 23 & Fombad, Madeleine; & 2 & 36 & 10 & Meyer, HWJ & 2 & I & 0.50 \\
\hline 37 & 18 & Bester, M & 7 & 105 & 23 & Geyser, E P & 2 & 37 & 10 & Mooko, NP & 2 & 0 & 0.00 \\
\hline 38 & 19 & Boekhorst, A K; & 6 & 106 & 23 & Gouws, A; & 2 & 38 & 10 & Olen, S & 2 & 1 & 0.50 \\
\hline 39 & 19 & Fairer-Wessels, F; & 6 & 107 & 23 & Grobler, P A & 2 & 39 & 10 & Onyancha, OB; & 2 & 3 & 1.50 \\
\hline 40 & 19 & Fourie, J A; & 6 & 108 & 23 & Harmse, C & 2 & 40 & 10 & Pienaar, $\mathrm{H}$; & 2 & 0 & 0.00 \\
\hline 41 & 19 & Hendrikz, F & 6 & 109 & 23 & Henning, J C; & 2 & 41 & 10 & Pretorius, EJ & 2 & 1 & 0.50 \\
\hline 42 & 19 & Kaniki, A M & 6 & 110 & 23 & Kiondo, E & 2 & 42 & 10 & Raubenheimer, J; & 2 & I & 1.50 \\
\hline 43 & 19 & Kiplang'at, J & 6 & 111 & 23 & Kloppers, M & 2 & 43 & 10 & Snyman, MMM; & 2 & 2 & 1.00 \\
\hline 44 & 19 & Louw, A & 6 & 112 & 23 & Kwake, Alice; & 2 & 44 & 10 & Underwood, PG; & 2 & I & 0.50 \\
\hline 45 & 19 & Lubbe, S; & 6 & 113 & 23 & Meyer, E & 2 & 45 & 10 & Weideman, M; & 2 & 2 & 1.00 \\
\hline 46 & 19 & Meyer, HWJ & 6 & 114 & 23 & Mountifield, HM; & 2 & 46 & 11 & Averweg, UR & 1 & 0 & 0.00 \\
\hline 47 & 19 & Onyancha, O B & 6 & 115 & 23 & Myburgh, S & 2 & 47 & 11 & Behrens SJ & 1 & 25 & 0.25 \\
\hline 48 & 19 & Raju, J S & 6 & 116 & 23 & Niemand, C J P; & 2 & 48 & 11 & Cloete, M; & I & 1 & 1.00 \\
\hline 49 & 19 & Walt, T B v d & 6 & 117 & 23 & Nkhata, B W M & 2 & 49 & 11 & Coetzee, HS; & 1 & 1 & 1.00 \\
\hline 50 & 19 & Brewis, W L E; & 6 & 118 & 23 & Oosthuizen, G J; & 2 & 50 & 11 & Doyle, D; du Toit, A & I & 1 & 1.00 \\
\hline 51 & 21 & Coetzee, H S; & 5 & 119 & 23 & Ovens, C S H & 2 & 51 & 11 & du Plessis, $T$ & 1 & 1 & 1.00 \\
\hline
\end{tabular}


5221 Kigongo-Bukenya, I M N 5

53 2I Leach, A; 5

$54 \quad 21 \quad$ Minishi-Majanja, MK 5

5520 Ponelis, S;

5620 Rensleigh, CW

5720 Swanepoel, A

5820 Terblanche, $F$

5920 Van Zijl, C;Gericke,E M 5

6020 Bruin, $\mathrm{Hd}$

6121 Burger, $M$

62 21 Cosijn, E;

6321 De Beer, F

6421 Dube, L

6521 Jacobs, D;

66 21 Mambo, H L

$6721 \quad$ Oosthuizen, B L

$6821 \quad$ Smith, J C;

\section{I20 23 Pansegrouw, J G 2}

$121 \quad 23$

$122 \quad 23$

$123 \quad 23$

$124 \quad 23$

$125 \quad 23$

$126 \quad 23$

$127 \quad 23$

$128 \quad 23$

$129 \quad 23$

$130 \quad 23$

$132 \quad 23$

$133 \quad 23$

$134 \quad 23$

$135 \quad 23$

$136 \quad 23$
Penzhorn, C

Petkov, Don

Radebe, $T$

Rowoldt, S

Shokane, j k

Thomson, J;

van den Berg, A

van Deventer, J P;

Niekerk, $\mathrm{H}$ v;

Walt, P W V D;

Venter, Rudi M R

Venter, $T$

Willemse, J

Witbooi, S L

Aitchison, Jean;
52 II Edwards, HM

53 II Harmse, C

54 II Hart, G

55 II Hendrikz, F

56 II Kigongo-Bukenya, IMN ।

57 II Le Roux, S

58 II Leach, A

59 II Morris, C

60 II Mountifield, HM

61 II Murray, K

62 II Nkhata, BWM

63 II Ponelis, SR

64 II Popoola, SO

65 II Swanepoel, A];

66 II van Niekerk, J

67 II Willemse, J
2.00

0.00

0.00

0.00

0.00

0.00

1.00

0.00

6.00

0.00

2.00

0.00

0.00

0.00

0.00

0.00

\subsection{The subject coverage}

Information science research by subject orientation has been offered special attention in the last decade, based on the recognition that LIS research output by subject is important in the establishment of research subject orientation for research planning and policy, identifying human resource development needs in the discipline, and in determining popular research topics for research partnership and graduate enrolment (see Ocholla 2000). It is recognised that there is no universally acceptable classification scheme of LIS by subject, and the bold attempts by Jarvelin and Vakkari in the last decade (see Rochester and Vakkari 1998) to establish a classification scheme or taxonomy have not been without criticism. Attempts to obtain usable subject taxonomy from LISA and ISI were unsuccessful, as LISA does not seem to offer one, while ISI categorisation (e.g. library science, information science, computer science or information systems, etc) is too broad. A subject descriptor in Library and Information Science Abstracts was therefore used to select the main/broad subject area arbitrarily for the analysis, as reflected in Table 3.

Table 3 Subject orientation

\begin{tabular}{|c|c|c|c|}
\hline Subject & Count & Subject & Count \\
\hline $\begin{array}{l}\text { Management- library management, knowledge management, } \\
\text { competitive intelligence, archives and records management, } \\
\text { information management }\end{array}$ & 143 & Information industry/sector, information society & 17 \\
\hline $\begin{array}{l}\text { Online information retrieval; computerized IR, S\&R, indexing, } \\
\text { abstracting }\end{array}$ & 119 & Academic libraries & 14 \\
\hline Information services & 107 & Reading/Readership- Children's libraries/Children's literature & 12 \\
\hline Information technology, ICTs, computer applications & 97 & School libraries; & 12 \\
\hline Professional education, LIS education and training & 89 & Intellectual property, copyright, plagiarism & 12 \\
\hline University libraries, academic libraries & 80 & Library and information science periodicals; & 11 \\
\hline Information communication/dissemination, publishing & 72 & National libraries; & 11 \\
\hline Librarianship & 62 & Bibliotherapy; & 3 \\
\hline Research & 49 & Library associations; & 3 \\
\hline Public libraries, South Africa & 48 & National bibliographies; & 3 \\
\hline Acquisitions. Collection development, library materials & 41 & Scholarly communication; & 3 \\
\hline Information literacy & 34 & Business management; & 2 \\
\hline Library and information science theory & 33 & Information sources; & 2 \\
\hline Information seeking & 25 & Library buildings; & 2 \\
\hline Bibliometrics/ informetics/ webometrics & 18 & Management; Leadership; & 2 \\
\hline Classification schemes; cataloguing, bibliographic control & 17 & Popular culture & 2 \\
\hline Access to information & 17 & Telecommunications industry; & 2 \\
\hline
\end{tabular}

The subject coverage in LIS is diversified and covers the core areas of LIS research. Dominant research areas are management (143), information retrieval (119), Information Services (107), ICTs (97), Education and Training (89) and Information Dissemination (72). 


\subsection{Research Collaboration}

The last part of this study focused on collaborative research output. Only data from the 256 records in ISI have thus far been used in the analysis. Research collaboration has a number of benefits, as outlined by Katz \& Martin (1997). Among them, according to the authors, are: that collaboration enables researchers to share skills and techniques, and is one way of transferring knowledge (especially tacit knowledge); through clashing views it may bring about the cross-fertilization of ideas, which may in turn generate new insights or perspectives that individuals, working on their own, would not have grasped; collaboration provides intellectual companionship (i.e. within a practising community); collaboration plugs the researcher into a wider contact network in the scientific community; and it enhances the potential visibility of the work. Thus, collaboration helps speed up problem solving, stimulates creativity and enables inter-disciplinary boundary crossing, which in turn enriches knowledge development and transfer.

A total number of 145 South African authored articles were published either by single authors or co-authored. Of the 145 , individual/single authored were $45(31 \%)$, two authors appeared $78(53.8 \%)$ times, three authors $17(11.8 \%)$, and four authors $4(2.8$. \%) times. There was one instance in which a single article $(0.6 \%)$ was published by 20 authors - an internal co-publication from the University of Pretoria. As to whether collaborative publication was internal, external, external but within South Africa, or external but with foreign countries, it turned out that of the 100 co-authored articles, 55 (55\%) were internal (i.e. published by colleagues from the same institution), and 45 (45\%) were external (published with colleagues from other institutions). External co-authorship with South African Institutions came to 23 of 45 (5I.2\%), external but with non-South African institutions totalled 20 of 45 (44.4\%), while external but involving both South African and foreign institutions produced 2 of 45 (4.4\%). Figure I and Table 4 shows the nature and type of research collaboration through single or multiple publications. Evidently, there are more co-authored articles (69\%) than singleauthored articles (31\%). Furthermore, there is limited external (45\%) collaboration within and outside the country. Even collaboration between institutions within the country is just slightly more than half $(55 \%)$ of all collaborations. Figure I shows the nature of institutional collaboration in the country.

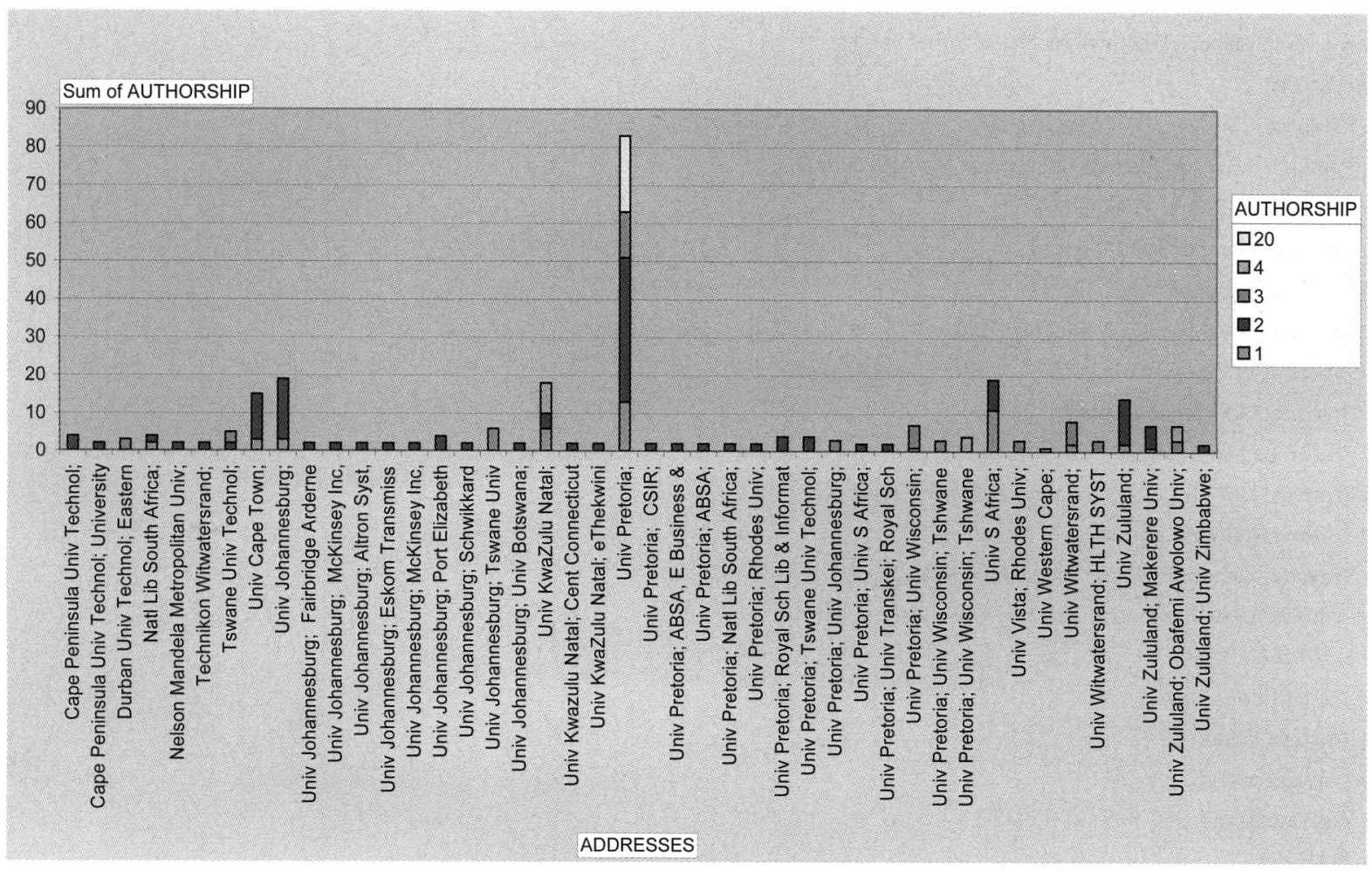

Figure 1 Nature of Collaboration

Information in the $y$ axis shows the number of single and collaborative publications by institution, while the $x$ axis provides information on the collaborating/non-collaborating institutions. Evidently, the Universities of Pretoria, Johannesburg, Cape Town, Kwazulu Natal and Zululand are leading collaborators. The leading collaborators are established researchers with eight or seven collaborative publications. Among them are Pieter van Brakel, Adelaide Du Toit, Peter Lor, Retha Snyman and Dennis Ocholla. Ina Fourie, Archie Dick and Patrick Ngulube were leading in terms of non-collaborative publications. 
Table 4 Type of Collaboration

\begin{tabular}{|c|c|c|c|c|c|c|}
\hline \multirow{2}{*}{$\begin{array}{l}\text { Count of Authorship } \\
\text { ADDRESSES }\end{array}$} & \multicolumn{6}{|c|}{ AUTHORSHIP } \\
\hline & 1 & 2 & 3 & 4 & 20 & Grand Total \\
\hline Cape Peninsula Univ Technol; & & 2 & & & & 2 \\
\hline Cape Peninsula Univ Technol; University of Botswana; & & । & & & & । \\
\hline Durban Univ Technol; Eastern Connecticut State Univ; & & & 1 & & & । \\
\hline Natl Lib South Africa; & 2 & I & & & & 3 \\
\hline Nelson Mandela Metropolitan Univ; & & । & & & & I \\
\hline Technikon Witwatersrand; & & । & & & & I \\
\hline Tswane Univ Technol; & & । & । & & & 2 \\
\hline Univ Cape Town; & 3 & 6 & & & & 9 \\
\hline Univ Johannesburg; & 3 & 8 & & & & 11 \\
\hline Univ Johannesburg; Fairbridge Arderne \& Lawton; & & 1 & & & & 1 \\
\hline Univ Johannesburg; McKinsey Inc, Johannesburg; & & । & & & & I \\
\hline Univ Johannesburg; Altron Syst, Johannesburg; & & । & & & & 1 \\
\hline Univ Johannesburg; Eskom Transmiss Grp, ZA; & & । & & & & 1 \\
\hline Univ Johannesburg; McKinsey Inc, Johannesburg; & & I & & & & 1 \\
\hline Univ Johannesburg; Port Elizabeth Technikon; & & 2 & & & & 2 \\
\hline Univ Johannesburg; Schwikkard Consulting; & & । & & & & I \\
\hline Univ Johannesburg; Tswane Univ Technol; & & & 2 & & & 2 \\
\hline Univ Johannesburg; Univ Botswana; & & 1 & & & & 1 \\
\hline Univ KwaZulu Natal; & 6 & 2 & & 2 & & 10 \\
\hline Univ Kwazulu Natal; Cent Connecticut State Univ; Eastern Connecticut State; & & । & & & & 1 \\
\hline Univ KwaZulu Natal; eThekwini Municipal; Univ Seville; & & 1 & & & & 1 \\
\hline Univ Pretoria; & 13 & 19 & 4 & & I & 37 \\
\hline Univ Pretoria; CSIR; & & 1 & & & & 1 \\
\hline Univ Pretoria; ABSA, E Business \& Informat Management Div; & & । & & & & 1 \\
\hline Univ Pretoria; ABSA; & & I & & & & 1 \\
\hline Univ Pretoria; Natl Lib South Africa; & & I & & & & 1 \\
\hline Univ Pretoria; Rhodes Univ; & & I & & & & I \\
\hline Univ Pretoria; Royal Sch Lib \& Informat Sci; & & 2 & & & & 2 \\
\hline Univ Pretoria; Tswane Univ Technol; & & 2 & & & & 2 \\
\hline Univ Pretoria; Univ Johannesburg; & & & 1 & & & 1 \\
\hline Univ Pretoria; Univ S Africa; & & । & & & & 1 \\
\hline Univ Pretoria; Univ Transkei; Royal Sch Lib \& Informat Sci; & & 1 & & & & 1 \\
\hline Univ Pretoria; Univ Wisconsin; & 1 & & 2 & & & 3 \\
\hline Univ Pretoria; Univ Wisconsin; Tshwane Univ Technol; & & & I & & & 1 \\
\hline Univ Pretoria; Univ Wisconsin; Tshwane Univ Technol; IFLA; & & & & 1 & & 1 \\
\hline Univ S Africa; & 11 & 4 & & & & 15 \\
\hline Univ Vista; Rhodes Univ; & & & 1 & & & I \\
\hline Univ Western Cape; & I & & & & & I \\
\hline Univ Witwatersrand; & 2 & & 2 & & & 4 \\
\hline Univ Witwatersrand; HLTH SYST TRUST; & & & 1 & & & 1 \\
\hline Univ Zululand; & 2 & 6 & & & & 8 \\
\hline Univ Zululand; Makerere Univ; & 1 & 3 & & & & 4 \\
\hline Univ Zululand; Obafemi Awolowo Univ; & & & I & । & & 2 \\
\hline Univ Zululand; Univ Zimbabwe; & & 1 & & & & 1 \\
\hline Grand Total & 45 & 78 & 17 & 4 & 1 & 145 \\
\hline
\end{tabular}

\section{Conclusions}

South African LIS researchers/authors largely publish in local journals (46.3\%), led by South African Journal of Library and Information Science-SAJLIS (25.1\%), Mousaion (11.9\%), and the South African Journal of Information Management (9.3\%). This figure would be higher if "Innovation" was included. Several factors contribute towards this trend. South Africa has a 
large pool/number of scholarly journals ( 255 titles) in all disciplines recognised and listed by the government for research recognition and subsidy, and the three cited journals are among six that fall within this category from the LIS discipline. Thus, South African researchers have sufficient (currently six as listed in section 3.I) internal, recognised scholarly/ academic journals in which they can publish research articles and be recognised and rewarded for doing so [nationally].

Publication in Thompson Scienctific/ISI and International Bibliography of Social Sciences (IBSS) indexed journals is also on the increase, based on similar recognition and rewards. Notably, while more South African based researchers publish in peer refereed LISA indexed LIS journals (250 authors), publication in ISI indexed journals (67 authors) is limited. The average citations ( 2.2 ratio) originating from the 256 articles is insignificant, although it differs less from the citation ratio in LIS alone and when compared to other social science disciplines, as observed by Onyancha (2007). Onyancha also reveals that although South Africa publishes most of Africa's LIS research, it receives comparatively fewer cites for its articles. Perhaps most articles are published in South African LIS journals (and other journals) none of which is indexed by ISI, or due to other reasons earlier cited from Calvert and Gorman (2002:I).

In terms of subject orientation, there is an impressive diversification and research focus on core areas of LIS education, such as management, information retrieval, services and dissemination, and the application of ICTs. Formidable niche areas seem to have been created by established academics, who continue to encourage more young researchers and publications in their fields of specialisation. However, we do not believe that this trend could lead to an oversaturation of specialists in a particular field at the expense of other less attended research domains. We believe that in a nascent democracy such as South Africa, specialisation should go hand in hand with diversification in order to enable the creation of capacity in marginalised fields. There is therefore potential for accelerated and enlarged publication output in the discipline in South Africa, provided that: novice/potential researchers (such as postgraduates) receive publication support from research supervisors, the government continues to pay subsidies to institutions based on accredited publication output, and institutional performance measurement indicators emphasise publication output. Thus, both quantity and quality can be maintained. The results relating to popular research topics have been compared to international trends reported by, for example, Maxine Rochester and Pertti Vakkari (1998).

Research collaboration as observed through co-authorship (69\%) is encouraging, as the bulk of such collaboration increasingly occurs between the research supervisor (of largely masters and doctorates), and the postgraduate student, who tends to be a member of the staff/faculty from the supervisor's academic institution. However, it was observed that inter-institutional research collaboration within South Africa is average (51.2\% of 45 ), and more or less similar between South African and non-South African institutions (44.4\%). We believe that inter-institutional research and international

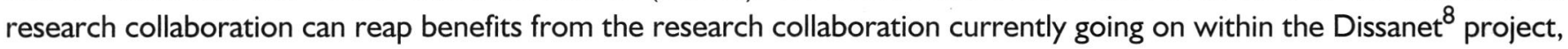
which focuses on promoting LIS research collaboration in South Africa. The increased research collaboration between established researchers and novice researchers and postgraduate students is commendable. We conclude that, since South Africa still leads in research and publication output in Africa (see Onyancha 2007), the rapidly growing research and publication output and support in the country offers promising opportunities for research and professional collaboration that could be explored and exploited beyond South Africa's borders.

This study is not inclusive or conclusive, as it only focused on research publication output appearing in peer refereed journals indexed in LISA and ISI Web of Science (SCI and SSCI) between 1993-2006, for reasons discussed in the introduction (section I). Other parts of the analysis, such as subject orientation and research collaboration (LISA is left out), are also incomplete. The study does not measure individual or institutional research output, which is more complicated (i.e. requires more variables). The question stands as to whether publication output in peer refereed journals can be used to measure/determine research output in a discipline such as LIS. We believe that an inclusive research agenda covering research quality, quantity, collaboration and diversification needs further exploration.

\section{Notes}

A version of this paper is prepared for the IFLA Conference in Durban, South Africa 19-24 ${ }^{\text {th }}$ August 2007

\section{References}

Aina, L.O.1998. Manuscripts Submitted for Publication in the Information Profession in Africa. Comparative of Rejected and Accepted Papers. Journal of Documentation, Vol.54, Number 2 (I998) 250 -25I.

Aina, L.O. and Mabawonku, L.M. 1997. The Literature of the Information profession in Anglophone Africa: Characteristics, Trends and Future Directions. Journal of Information Science, Vol. 23, No, 4, 32I-326.

Aina, L. O. \& Mooko, N. P. 1999. Research and publication patterns in library and information science, Information Development, I5(2):114-II9. 
Alemna, A. A. 1996. The Periodical Literature of Library and Information Science in Africa: 1990- 1995. International Information and Library Review, 28 (2) 93- 103.

Alemna, A. A. 200I. The periodical literature of library and information in Africa: 1996-2000. Information Development; December 200I, Vol. 17 Issue 4, p257-26I, 5p.

Alemna, A.A. and Badu, E. 1994. The Nature and Trends in Research and Journal Literature in English Speaking Africa. International Information and Library Review, Vol.26, No I, 19-3I.

Boon, J.A. and van Zyl, E.R. 1990. State of the art of research in Library and Information science in South Africa: a macro analysis. South African Journal of Library and Information Science Vol. 58 No. 2, I55-I66.

Calvert, P.J. and Gorman, G.E.2002. Testing Article Quality in LIS Journals: The Search Continues. 68 ${ }^{\text {th }}$ IFLA Council and General Conference, August 18-24, code Number 169-I I8-E, Division Number VII, Library and Information Science Journals.

Diodato, V. 1994. Dictionary of Bibliometrics. New York: Haworth.

Garfield, E. 1998. The Multiple meaning of impact factors. Journal of American Society for Information Science, 49(8), 768.

Garfield, E. 1996. Citation indexes for retrieval and search evaluation. Paper presented at Consensus Conference on the Theory and Practice of Research Assessment, Capri, October $7^{\text {th }}$, [Online] http://garfield.library.upenn.edu. Accessed 20 April 2007.

Garfield,E. 1994. The ISI impact factor. Current contents June 20. [Online] http://scientific.thomson.com/free/essays/ journalcitationreports/usingimpactfactor/ Accessed $26^{\text {th }}$ May 2007

Garfield, E. 1972. Citation analysis as a tool in journal evaluation. Science 178,47|-479.

Garfield,E. I97I. Publication counting vs citation counting in evaluating research, Essays of an Information Scientist, I,: I79-181.

Gorman, G.E. 2000.Authors and Editors of Library Science Journals: Reflections from an Asian/Pacific Context. Libri, Vol.50, 98103.

Harnad, Stevan. 1998. The invisible hand of peer review.[Online] http://www.nature.com/nature/wematters/invisible/invisible.html accessed 22 September 2006.

Harnad, S. 1995 Implementing Peer Review on the Net: Scientific Quality Control in Scholarly Electronic Journals. In: Peek, R. \& Newby, G. (Eds.) Electronic Publishing Confronts Academia: The Agenda for the Year 2000. Cambridge MA: MIT Press. [Online].Available: ftp://cogsci.ecs.soton.ac.uk/pub/harnad/Harnad/harnad95.peer.review/

Kadiri, J. 200 I. Library literature in Ghana, 1950- 1994. African Journal of Library, Archives \& Information Science, I I (2):89-95.

Katz, J.S. \& Martin, B.R. 1997. What is research collaboration? Research policy, 26(I): I-18

Mabawonku, I. 200I.Trends in Library and Information Science Research in Africa, 1991 -2000. African Journal of Library, Archives, and Information Science, II(2): 79-88.

Ngulube, P. 2005a. Improving the quality of research output in higher education through knowledge sharing and collaboration: A case study. Mousaion, Vol.23, I,39-4I.

Ngulube, P. 2005b. Research procedures used by master of Information Studies students at the University of Natal in the period 1982-2002 with special reference to their sampling techniques and survey response rates. A methodological discourse. International Information and Library Review, Vol 37, I, I 27 - I43.

Ocholla, DN. 2000. Research Capacity in Library and Information Science in South Africa. $66^{\text {th }}$ IFLA General Conference, $13-18$ August, Jerusalem, Israel (see. http://www.ifla.org//V/ifla66/papers/054-/27e.htm)

Ocholla, DN. 200I. An informetric analysis of research capacity in Library and Information Science in South Africa. Proceedings of the International Sciencetometric and Informetric Conference vol.2 Sydney, Australia 16 - 20 July, UNSW, pp. 867-869.

Onyancha, B. 2007. LIS research in Africa: how much is it worth? A citation analysis of the literature, 1986-2006. $73^{\text {th }}$ IFLA General Conference, 13 - 18 August, Durban, South Africa (preprint).

Rochester, M. \& Vakkari, P. 1998. International LIS Research: A Comparison of National Trends. IFLA Journal 24, I66- 175 